\title{
Search for new drugs as pharmacological targets
}

\author{
Ana María Plutín Stevens*, Raúl Ramos Cairo and Raúl Mocelo Castell \\ Laboratory of Organic Synthesis, Faculty of Chemistry, University of Havana, Havana, Cuba
}

\section{Introduction}

Among the most effective agents for the treatment of cancer there are some metallodrogas based on cisplatin causing great interest in the search of antitumor agents that are more effective and with fewer side effects [1]. It is known that Mycobacterium tuberculosis, the causative agent of tuberculosis, is responsible for the death of around 1.73 million people annually. The increase of resistance to multiple drugs and the little development of new specific compounds, has complicated and prolonged the treatment of tuberculosis [2,3].

On the other hand, Chagas disease, caused by the parasite Tripanosoma cruzi (T. cruzi), affects approximately 7 million people worldwide, with a high prevalence in Latin America [4].

The few medications available, for their treatment benznidazole and nifurtimox, are only effective when administered during the acute phase, but are not effective in patients who have moved into the chronic phase [5]. In addition, these medications are not considered ideal, due to their serious side effects [4], thus the search for new antiparasitics is also necessary.

The Laboratory of Organic Synthesis of the Faculty of Chemistry of the University of Havana has as a priority the obtaining of new molecules that present biological activity, from which drugs can be obtained for the treatment of diseases such as cancer, tuberculosis and Chagas disease, which are latent diseases in our country and Latin America.

Within this, thematic one has experience in the preparation of Organic compounds and their metallic complexes with potential biological activity in vitro.

In general, the search for bioactive compounds has become an object of study in different Research Institutions. In particular, the drugs designed for the treatment of diseases such as cancer, tuberculosis and American trypanosomiasis have been increasing in the search for a better quality of life of the patient developing.

Copyright: (C2018 Stevens AMP. This is an open-access article distributed under the terms of the Creative Commons Attribution License, which permits unrestricted use, distribution, and reproduction in any medium, provided the original author and source are credited.

\section{Results}

The in vitro antitumor activity of the ligands and their metal complexes were evaluated tumor cells DU-145 (prostate cancer cells), (MDA-MB-231 (breast cancer cells), L929 (healthy cells of mouse), antibacterial against strains of $M$. tuberculosis $\mathrm{H} 37 \mathrm{Rv}$ and antiparasitic against epimastigotes of Trypanosoma cruzi. Of the exposed results, eight of the thirty-two metal complexes were active against the evaluated targets [6-8].

The results obtained lie in the contribution to scientific knowledge and can contribute to the development of new medicines to provide a better quality of life for people.

\section{References}

1. Pracharova J, Zerzankova L, Stepankova J, Novakova O, Farrer NJ, et al. (2012) Interactions of DNA with a new Platinum(IV) Azide Dipyridine complex activated by UVA and visible light: relationship to toxicity in tumor cells. Chem Res Toxicol 25: 1099-1111.

2. Gagneux S (2018) Ecology and Evolution of Mycobacterium Tuberculosis. Nat Rev Microbiol p:1-12.

3. Halim Abd NA, Ngaini Z (2017) Synthesis and characterization of halogenated bis(acylthiourea) derivatives and their antibacterial activities. Phosphorus, Sulfur Silicon Relat Elem 192: 1012-1017.

4. Jones A, Versteeg L, Damania A, Keegan B, Kendricks A, et al. (2018) Vaccine-linked chemotherapy improves benznidazole efficacy for acute Chagas disease. Infect Immun 86: 876-917.

5. Urbina JA (2010) Specific chemotherapy of Chagas disease: Relevance, current limitations and new approaches. Acta Tropica 115: 55-68.

6. Plutín AM, Mocelo R, Álvarez A, Ramos R, Castellano EE, et al (2014) On the cytotoxic activity of $\mathrm{Pd}(\mathrm{II})$ complexes of $\mathrm{N}, \mathrm{N}$-disubstituted-N'-acyl thioureas. J Inorg Biochem 134: 76-82.

7. Plutín AM, Alvarez A, Mocelo R, Ramos R, Castellano EE, et al. (2016) AntiMycobacterium tuberculosis activity of platinum(II)/ N,N-disubstituted-N'acylthiourea complexes. Inorg Chem Com 63: 74-80.

8. Plutín AM, Álvarez A, Mocelo R, Ramos R, Castellano EE, et al. (2017) Palladium(II)/ $\mathrm{N}, \mathrm{N}$-disubstituted-N'-acylthioureas complexes as anti-Mycobacterium tuberculosis and anti-Trypanosoma cruzi agents. Polyhedron 132: 70-77.
*Correspondence to: Ana María Plutín Stevens, Laboratory of Organic Synthesis, Faculty of Chemistry, University of Havana, Havana, Cuba, E-mail: anap@fq.uh.cu

Key words: bioactive compounds, diseases, cancer, tuberculosis, chagas, quality of life of the patient

Received: December 21, 2018; Accepted: December 28, 2018; Published: December 31, 2018 